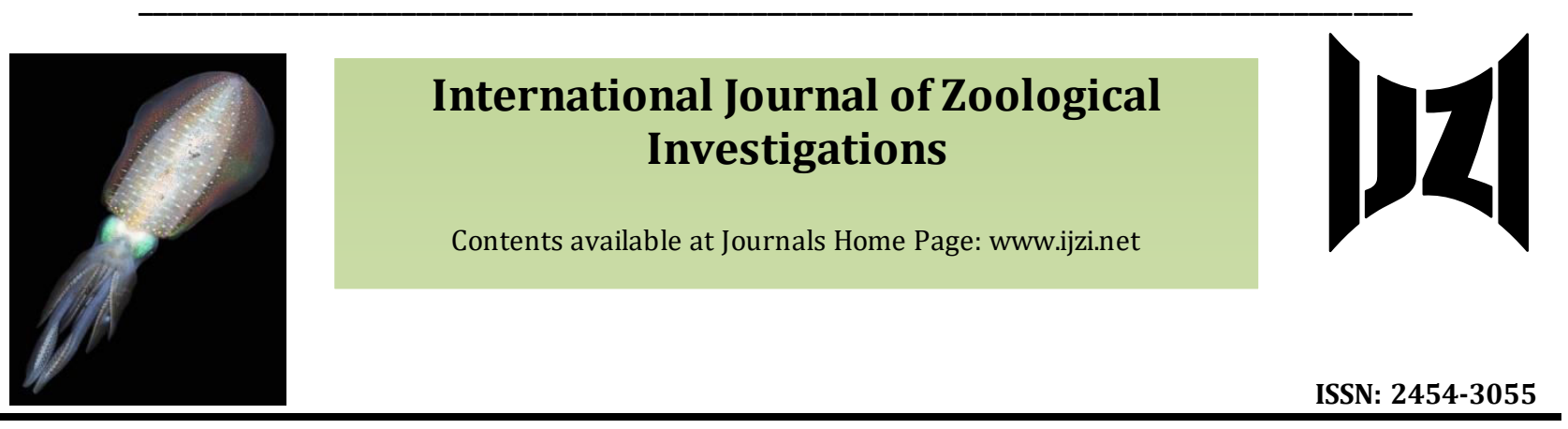

\title{
Biodiversity Assessment of Chironomids (Diptera: Chironomidae) in Rajsamand Lake (Rajsamand, Rajasthan, India)
}

\author{
Prajapat Gyata* and Rawal Deepak \\ Department of Zoology, Mohanlal Sukhadia University, Udaipur, Rajasthan 313001, India \\ ${ }^{*}$ Corresponding Author
}

Received: $24^{\text {th }}$ January, 2021

Accepted: $14^{\text {th }}$ March, 2021

Published online: $19^{\text {th }}$ March, 2021

https://doi.org/10.33745/ijzi.2021.v07i01.009

\begin{abstract}
Present study was performed for taxonomic identification, assemblage, richness, spatial distribution and abundance analysis of chironomid larvae in the benthic and lentic shoreline habitat of Rajs amand Lake, India. Chironomids play an important role in shallow water aquatic ecosystems, so this study will give an idea about ecology of this area. Topographical and environmental factors are strongly correlated with the composition of chironomid communities. No information is available regarding these organisms in this defined area, so this study would provide data for comparison with chironomid community present in nearby and other ar ea, where study on chironomids is already done or will be done. This study on chironomids was conducted for the first time in Rajs amand Lake, India. Specim ens were collected at seven sampling sites along shoreline of the Lake. A total of four genera (viz. Chironomus, Cryptochironomus, Einfeldia and Polypedilum) were reported. Polypedilum was the most dominant genus reported followed by Chironomus, Einfeldia and Cryptochironomus. Genus Cryptochironomus was reported for the first time in Rajasthan.
\end{abstract}

Keywords: Chironomids, Rajsamand Lake, Biodiversity, Chironomus, Cryptochironomus, Einfeldia, Polypedilum

Citation: Prajapat Gyata and Rawal Deepak: Biodiversity assessment of Chironomids (Diptera: Chironomidae) in Rajsamand Lake (Rajsamand, Rajasthan, India). Intern. J. Zool. Invest. 7 (1): 90-97, 2021.

https: //doi.org/10.33745/ijzi.2021.v07i01.009

\section{Introduction}

Biodiversity is the study of variation of particular clade. However, exact measure of biodiversity in a defined area is difficult to estimate but random sampling always help to assume the ratio of particular taxa.
Biodiversity of taxa is linked with environmental factors and exploitable resources in a defined area (Fesl, 2002). Chironomids are a group of holometabolous cosmopolitan group of aquatic dipterans. They 
show metamorphosis with ecdysis and usually have four instars. They are known by many names such as lake flies, blind mosquitoes, muffleheads, chizzywinks, bloodworms, choira etc. Their sensitivity to changing environmental conditions makes them potential bioindicators in both lacustrine and riverine habitats (Armitage et al., 1995). These organisms were influenced over time by a range of indirect and direct variables such as human activity, which affect aquatic habitats in many ways (Antczak-Orlewska et al., 2021). Biotic factors are important in determining zoobenthos communities in shallow lakes and chironomids are very good indicators of past changes in primary production (Langdon et al., 2010). Most chironomids are detrivores and feed on phytoplankton, zooplankton and decaying organic matter. Most larvae lives in tubes built of sediment (Armitage et al., 1995). They are very considerable diet for fish, aquatic birds and other aquatic invertebrates (Leonard and Ferrington, 2008). Chironomids are ignored by many researchers due to difficulties faced in identification and scarcity of literatures. They can be identified up to species level only by rearing adult males or through DNA barcoding (Brodin et al., 2013). Further documentation and databases of this fauna throughout the globe is also not complete (Armitage et al., 1995). A phylogeny based on cladistic analysis of chironomids subfamilies was proposed by Saether (2000). The chironomids has high adaptability to survive under widely different climatic conditions such as $\mathrm{pH}$, temperature, salinity and low oxygen, where many other organisms cannot (Acosta and Prat, 2010; Cao et al., 2019; Belle and Goldkoop, 2021). Chironomids have also been reported from glacial melt stream at
5600 meter above sea level in Himalaya Mountains (Koshima, 1984). The deformities in mouthparts especially in mentum are used in biomonitoring pragrammes to obtain information about organic and chemical pollution of aquatic water bodies and their catchments (Morais et al., 2010). Topographical and environmental factors such as altitude, latitude, vegetation, drainage, temperature, area size, eutrophication etc. affect their spatial distribution and assemblage (Rossaro, 1991). Their fossils are also used in palaeolimnology to guess past climatic change (Brodersen and Quinlan, 2006). Chironomids have both negative and positive impact on humans. Negative impact includes nuisance species that acts as paddy pest, allergens and host for pathogenic bacteria (Broza and Halpern, 2001). Positive impact includes, essential role in nutrient cycling, energy flow, biofiltering and food for freshwater commercial and sport fisheries (Rawal et al., 2018, 2019; Arkia et al., 2019).

This study was performed for taxonomic identification, assemblage, richness, spatial distribution and abundance analysis of chironomid larvae in the benthic and lentic shoreline habitat of Rajsamand Lake, India.

\section{Materials and Methods}

Rajsamand Lake also known as Rajsamudra Lake (Fig. 1) was built in $17^{\text {th }}$ century by Rana Raj Singh. It has shoreline of about $15 \mathrm{~km}$ and surface area of approximately $9 \mathrm{~km}^{2}$. This is a eutrophic Lake which has shoreline development index of about 1.4102. Maximum depth of this lake is about 18 meters. Lake is on altitude of approximately 550 meter above sea level. Primary inflow is of Gomati River and Nandsamand Dam (Naruka and Sharma, 2017). 


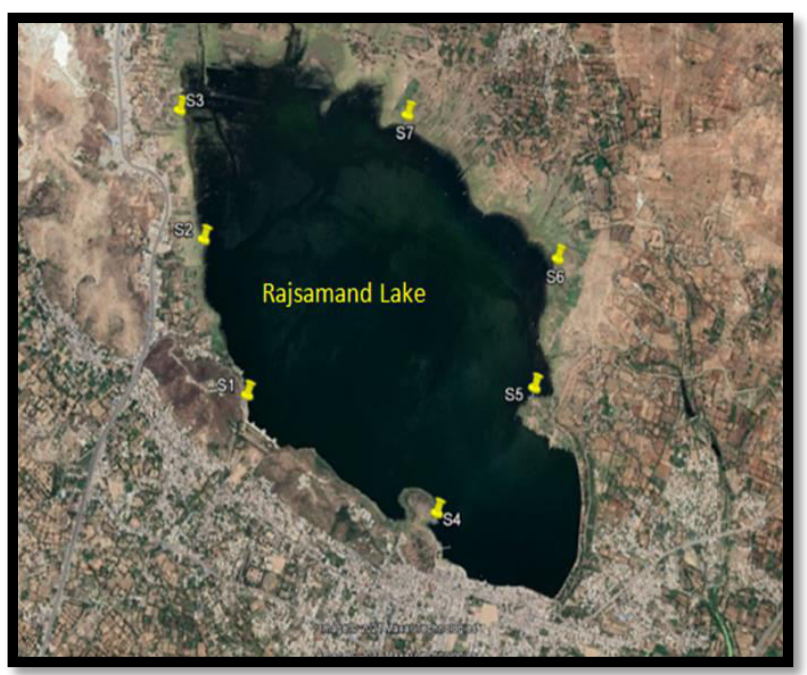

Figure 1: Satellite map showing study area and sampling sites (Courtesy: Google Earth)

Random sampling was done at seven sites -- S1-S7 (Fig. 1) with three repetitions on each site in the months of November 2019 to March 2020. Since they are ephemeral, univoltine and semelparous, no seasonal sampling were required. Modified partial quadrant method was used to collect larvae in per square meter area. Since chironomids larvae are found in sediment of shoreline, no deep water sampling was required. Latitudes, longitudes and altitudes of sampling sites were measured using GPS of Smartphone. Larval samples were collected by sieving sediment substrate in bucket, then larvae were carried alive in plastic bottles and labeled with sampling site. After carried to the laboratory, they were counted and sorted for further biodiversity analysis. Larvae were preserved in $70 \%$ alcohol and mounted on DPX. Then sorting and identification of these mounted larvae was done up to genera level under microscope (50-1000x magnification) using keys (Epler, 2001). In order to examine significant difference in larval density among sampling sites standard deviations and standard errors of means were calculated for each sampling sites. For comparison of biodiversity among seven sampling sites, Shannon-Weiner and Simpson indices were calculated. Shannon index is an informative index which considers all taxa randomly but Simpson index focuses more on dominant taxa. Evenness index were calculated for assessment of equitability and Dominance index for assessment of Dominance among sampling sites. Statistical analyses were done using Microsoft Excel and Past software (Version 4.05). Shannon-Weiner, Simpson indices and Pielou's Eveness index were calculated as ---

Shannon-Weiner diversity index $(\mathrm{H})=-\Sigma[(\mathrm{pi}) *$ In (pi) $]$ where, $\Sigma=$ summation; pi = ratio of samples upon total sum of samples

Simpson diversity index (D) $=1-[\Sigma \mathrm{n}(\mathrm{n}-1) / \mathrm{N}(\mathrm{N}-1)]$

where, $\Sigma$ =summation; $\quad \mathrm{N}=$ total number of individuals of all taxa; $\mathrm{n}=$ number of individuals in particular taxa

Pielou's Eveness index $(\mathrm{E})=\mathrm{H} / \mathrm{Hmax}$

where, $\mathrm{H}=$ Shannon-Weiner index; $\quad H m a x=$ maximum diversity possible

Dominance index $=1-\mathrm{D}$

where D is Simpson diversity index

\section{Results and Discussion}

Chironomids larvae were sorted among other aquatic larvae using distinguished features such as red color, absence of spiracles, prologs on first thoracic and terminal abdominal segments. Larval mouthparts are adapted to their diet. Mentum, mandibles and ventromental plates are key features for morphological identification in our study. Subfamily Chironominae was confirmed using distinguished features such as presence of mentum with 12 teeth, one or two pair of eye spots, striated ventro-mental plates and antennae with five segments. However, taxonomic species identification of larval chironomids is time consuming and difficult due to morphological similarities in them. 
Table 1: Data of sampling and mean larval density

\begin{tabular}{|c|c|c|c|c|c|c|}
\hline Sampling Sites & Sampling 1 & Sampling 2 & Sampling 3 & $\begin{array}{c}\text { mean density } \\
\left(n / m^{2}\right)\end{array}$ & S. D. & S. E. \\
\hline Site 1 & 116 & 94 & 106 & 105.33 & 11.02 & 4.16 \\
\hline Site 2 & 214 & 132 & 181 & 175.66 & 41.26 & 15.59 \\
\hline Site 3 & 106 & 83 & 94 & 94.33 & 11.50 & 4.35 \\
\hline Site 4 & 93 & 75 & 86 & 84.66 & 9.07 & 3.43 \\
\hline Site 5 & 41 & 20 & 31 & 30.66 & 10.50 & 3.97 \\
\hline Site 6 & 64 & 48 & 57 & 56.33 & 8.02 & 3.03 \\
\hline Site 7 & 103 & 83 & 91 & 92.33 & 10.07 & 3.80 \\
\hline
\end{tabular}

DNA barcoding using COI (cytochrome oxidase I) gene is useful for species confirmation but due to their abundance and absence of available GenBank database, it is also not feasible for all collected larvae. Chironomid species identification and confirmation using chromosomes is also not possible due to chromosomal polymorphism amongst members of same species. So in this study identification of larval chironomids is limited up to genera level. At site 2 larval chironomid densities was reported maximum and at site 5, it was reported minimum. Overall mean density of larval chironomids along shoreline of Rajsamand Lake is $91.32 / \mathrm{m}^{2}$ (Table 1).

The family Chironomidae is one of the most abundant dipterans group present in all zoogeographical regions (Leonard and Ferrington, 2008). Review of records and species accounts confirms a total of eleven subfamilies (viz. Aphroteniinae,
Buchonomyiinae, Chilenomyiinae, Chironominae, Diamesinae, Orthocladiinae, Podonominae, Prodiamesinae, Tanypodinae, Telmatogetoninae and Usumbaromyiinae), which further grouped in 22 tribes and 339 genera and more than 4000 reported species but it estimates that more than 10000 species may be present (Ashe, 1983). In oriental region total 105 genera and more than 350 species are reported. In India there are four reported subfamilies (viz. Chironominae, Diamesinae, Orthocladiinae and Tanypodinae) with 313 species under 60 genera (Chaudhuri et al., 2001). Few recent studies have been done on chironomids in Rajasthan, India. First chironomid species reported in Rajasthan (Jaipur) was Chironomus circumdatus (Sharma and Gupta, 2014). Later we also reported a new species Einfeldia pritiensis in Udaipur (Singh and Rawal, 2016 a). We also reported three genera (viz. Chironomus, Einfeldia and Polypedilum) from lakes (Fatehsagar, Pichola and Udaisagar) of Udaipur region (Singh and 
Table 2: Genera recorded along sampling site

\begin{tabular}{|c|c|c|c|c|c|c|c|c|}
\hline Genera & Site 1 & Site 2 & Site 3 & Site 4 & Site 5 & Site 6 & Site 7 & Total \\
\hline Polypedilum (Kieffer) & 105 & $\mathbf{1 8 8}$ & 95 & 93 & $\mathbf{4 0}$ & 70 & 103 & 692 \\
\hline Chironomus (Meigen) & 89 & $\mathbf{1 5 8}$ & 87 & 82 & $\mathbf{2 6}$ & 50 & 80 & 572 \\
\hline Einfeldia (Kieffer) & 81 & $\mathbf{1 3 0}$ & 76 & 62 & $\mathbf{2 1}$ & 40 & 69 & 479 \\
\hline Cryptochironomus (Kieffer) & 27 & $\mathbf{3 2}$ & 15 & 9 & $\mathbf{3}$ & 4 & 14 & 104 \\
\hline Not identified & 14 & 19 & 10 & 8 & 2 & 5 & 11 & 69 \\
\hline Total & 316 & $\mathbf{5 2 7}$ & 283 & 254 & $\mathbf{9 2}$ & 169 & 277 & 1918 \\
\hline
\end{tabular}

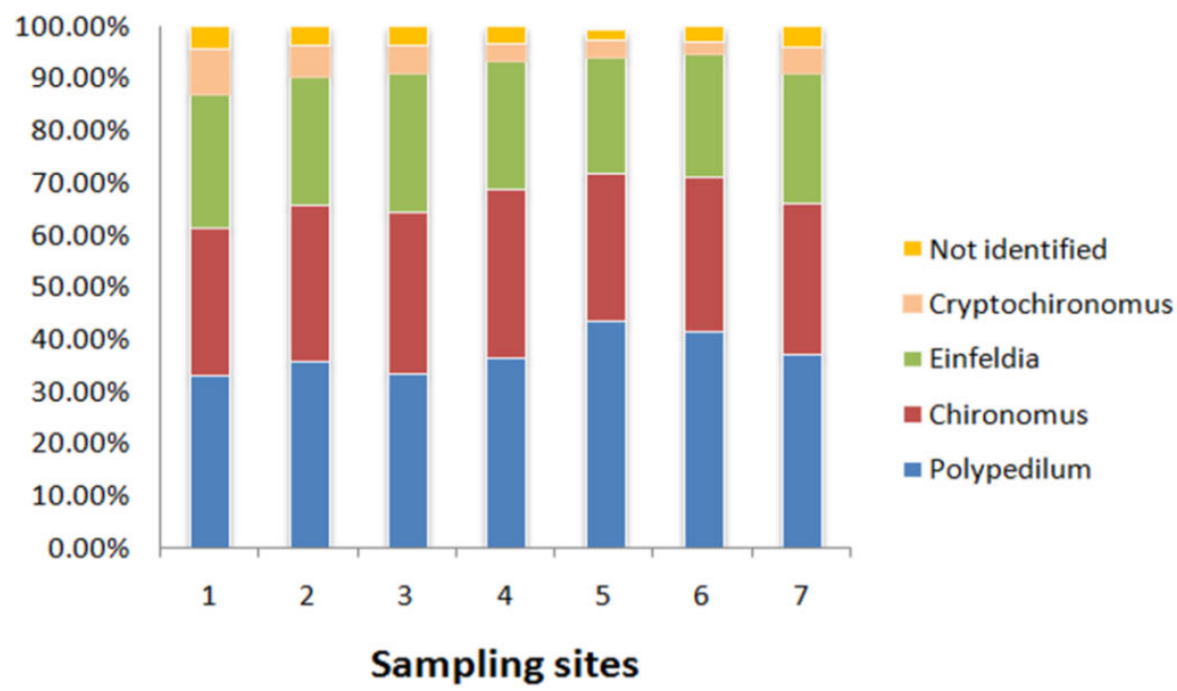

Fig. 2: Bar graph showing relative abundance of chironomid genera (site wise)

Rawal, 2016 b), which are about $55 \mathrm{~km}$ (straight distance) away from present study site. Four genera (viz. Chironomus, Clinotanypus, Einfeldia and Polypedilum) were also reported recently from Jaisamand Lake which is $90 \mathrm{~km}$ (straight distance) from current study area (Verma and Rawal, 2021). A total of four genera (viz. Chironomus, Cryptochironomus, Einfeldia and Polypedilum) were reported. Polypedilum was the most dominant genus reported followed by Chironomus, Einfeldia and Cryptochironomus
(Table 2; Fig. 2). Genus Cryptochironomus was reported for the first time in Rajasthan. All four reported genera belong to subfamily Chironominae and Tribe Chironomini.

Study on chironomids of Rajasthan is very rare. This study will also help to understand the taxonomic diversities of chironomids in Rajsamand Lake. A total of four genera (viz. Chironomus, Cryptochironomus, Einfeldia and Polypedilum) were identified with dominant genus Polypedilum. Polypedilum was found to be most dominant (36\%) among four 


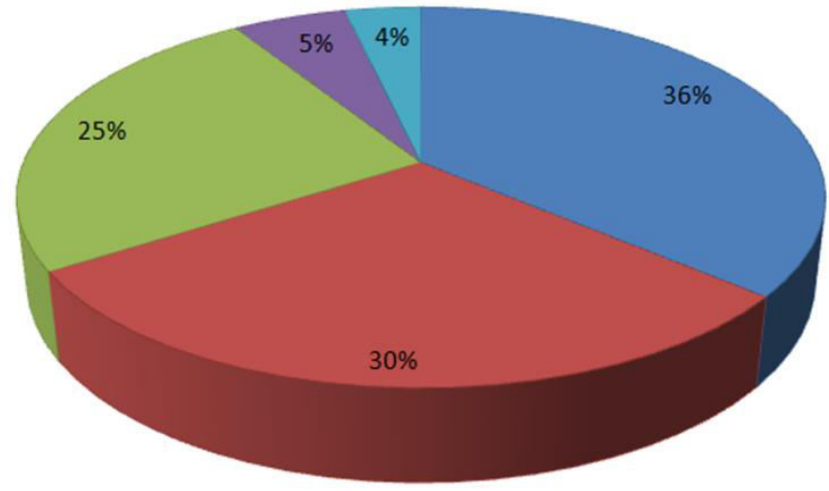

Figure 3: Pie graph showing relative abundance of chironomid genera (overall)

Table 3: Diversity indices obtained for sampling sites

\begin{tabular}{|l|l|l|l|l|l|l|l|}
\hline Diversity Indices & Site 1 & Site 2 & Site 3 & Site 4 & Site 5 & Site 6 & Site 7 \\
\hline Individuals & 302 & $\mathbf{5 0 8}$ & 273 & 246 & $\mathbf{9 0}$ & 164 & 266 \\
\hline Shannon index (H) & $\mathbf{1 . 2 9 6}$ & 1.254 & 1.247 & 1.202 & 1.172 & $\mathbf{1 . 1 6}$ & 1.234 \\
\hline Simpson index (D) & $\mathbf{0 . 7 1 2 3}$ & 0.6969 & 0.6968 & 0.6811 & $\mathbf{0 . 6 6 3 5}$ & 0.6648 & 0.6896 \\
\hline Dominance index (1-D) & $\mathbf{0 . 2 8 7 7}$ & 0.3031 & 0.3032 & 0.3189 & $\mathbf{0 . 3 3 6 5}$ & 0.3352 & 0.3104 \\
\hline Evenness index (E) & $\mathbf{0 . 9 1 3 9}$ & 0.8761 & 0.8701 & 0.832 & 0.8072 & $\mathbf{0 . 7 9 7 7}$ & 0.8585 \\
\hline
\end{tabular}

reported genera. Chironomus (30\%) was found second most dominant genus. Einfeldia (25\%) was at third place in dominance and least reported genus was Cryptochironomus (5\%) (Fig. 3). The maximum diversity of chironomid genera was reported at site 1 and minimum at site 6 (Shanon-Weiner Index) and site 5 (Simpson index). Maximum dominance of chironomids was reported at site 5 and minimum at site 1 . Maximum evenness index was reported at site 1 and minimum at site 6 (Table 3).

\section{Conclusion}

Four genera were identified in this Lake, (viz Chironomus, Cryptochironomus, Einfeldia and Polypedilum). Polypedilum was the most dominant genus reported followed by Chironomus, Einfeldia and Cryptochironomus. All four reported genera belong to subfamily Chironominae and Tribe Chironomini. Three genera (viz. Chironomus, Einfeldia and Polypedilum) were also previously reported in Udaipur region, which is about $50 \mathrm{~km}$ 
(straight distance) away from this site. Genus Cryptochironomus was reported for the first time in Rajasthan. This study proposes a general pattern of biodiversity, distribution and abundance of chironomids along shoreline of Rajsamand Lake. This study will also give an idea about ecology of this area because environmental factors are strongly correlated with the composition of chironomid communities. This study will provide basic data for comparison of chironomid community present in nearby and other areas as well as their use as potential bioindicators in this water body.

\section{References}

Acosta R and Prat N. (2010) Chiro nomid assem blages in high altitude streams of the Andean region of Peru. Fundamental Applied Limnol.177: 57-79..

Antczak-Orlewska 0, Plociennik M, Sobczyk R, Okupny D, Stachowicz-Rybka R, Rzodkiewicz M, Sicinski J, Mroczkowska A, Krapiec M, Slowinski M and Kittel P. (2021) Chironomidae morphology types and functional feeding groups as a habitat complexity vestige. Front Ecol Evol. 8: 583831. https://doi.org/10.3389/fevo.2020.583831.

Arkia S, Siahkalroudi SY and Kheradpir N. (2019) Chironomidae (Insecta: Diptera) biodiversity at generic level in Lar River, Tehran Province with introducing two new genera from Iranian fauna. J Wildlife Biodiver. 3: 31-39.

Armitage PD, Cranston PS and Pinder LCV. (1995) The Chironomidae: Biology and ecology of non-biting midges. $1^{\text {st }}$ ed. Chapman and Hall, London, pp. 1-538.

Ashe P. (1983) A catalogue of chironomid genera and subgenera of the world including synonyms (Diptera: Chironomidae). Entomol Scandin. 17:1-68.

Belle S and Goedkoop W. (2021) Functional diversity of chironomid communities in subarctic lakes across gradients in temperature and catchment characteristics. Limnol. 22: 5-16.

Brodersen KP and Quinlan R. (2006) Midges as palaeoindicators of lake productivity, eutrophication and hypolimnetic oxygen. Quat Sci Rev. 25: 1995-2012.
Brodin Y, Edjung G, Strandberg J and Lytholm T. (2013) Improving environmental and biodiversity monitoring in the Baltic Sea using DNA barcoding of Chironomidae (Diptera). Molec. Ecol Resour. 13: 996-1004.

Broza M and Halpern M. (2001) Chironomid egg masses and Vibrio cholera. Nature, 412: 40.

Cao Y, Langdon PG, Yan Yi, Wang S, Zheng Z and Zhang Z. (2019) Chironomid communities from subalpine peatlands in subtropical China as indicators of environmental change. J Paleolimnol. 62: 165-179.

Chaudhuri PK, Hazra N and Alfred JRB. (2001) A checklist of Chironomid midges (Diptera: Chironomidae) of the Indian subcontinent. Oriental Insects 35: 335-372.

Epler JH. (2001) Identification manual for the larval Chironomidae (Diptera) of North and South Carolina, $1^{\text {st }}$ ed. North Carolina Department of Environment and Natural Resources Division of Waterr Quality, USA, pp.1-526.

Fesl Christian. (2002) Biodiversity and resource use of larval chironomids in relation to environmental factors in a large river. Freshw Biol. 47: 1065-1087.

Koshima S. (1984) A novel cold-tolerant insect found in a Himalayan glacier. Nature 310: 225-227.

Leonard C and Ferrington Jr. (2008) Global diversity of non-biting midges (Chironomidae; Ins ecta-Diptera) in freshwater. Hydrobiol. 595: 447-455.

Langdon PG, Ruiz Z, Wynne S, Sayer CD and Davidson TA. (2010) Ecological influences on larval chironomids communities in shallow lakes: implications for palaeolimnological interpretations. Freshw Biol. 55: 531-545.

Morais SS, Molozzi J, Viana AL, Viana TH and Callisto M. (2010) Diversity of larvae of littoral Chironomidae (Diptera: Ins ecta) and their role as bioindicators in urban reservoirs of different trophic levels. Braz J Bio. 70: 995-1004.

Naruka S and Sharma MS. (2017) Water quality assessment of Rajsamand Lake, Rajasthan, India. Intern Res J Environ Sci. 6: 22-28.

Prat N, Punti T and Rieradevall M. (2016) The use of larvae and pupal exuviae to study the biodiversity of Chironomidae in Mediterranean streams. J Entomol Acarolog Res. 48: 29-36, 2016.

Rawal D, Prajapat G and Verma H. (2019) Status of Chironomids (Diptera) as potential bioindicators. Intern J Adv Sci Res Manag. 4: 154-156. 
Rawal D, Verma H and Prajapat G. (2018) Ecological and economic importance of Chironomids (Diptera). J Emerg Technol Innov Res. 5: 693-696.

Rossaro B. (1991) Factors that determine Chironomidae species distribution in fresh waters. Indian J Zool. 58: 281-286.

Saether OA. (2000) Phylogeny of the subfamilies of Chironomidae (Diptera). Syst Entomol. 27: 290-302.

Sharma MR and Gupta V. (2014) Morphological identification of Chironom us larvae in Jai pur district (Rajasthan) India. Intern J Sci Res. 3: 411-413.
Singh P and Rawal D. (2016 a) Biodiversity of Chironomidae (Diptera) from Udaipur region (India). Intern J Adv Res. 4: 502-505.

Singh P and Rawal D. (2016 b) Einfeldia pritiensis, a new species of Chironomidae (Diptera) from Udaipur region (Rajasthan, India). J Entomol Zoology Stud. 4: 319-320.

Verma H and Rawal D. (2021) Biodiversity analysis of Chironomids (Diptera) in Jaisamand Lake (Udaipur, Rajasthan). Intern J Entomol Res. 6 (in press). 